\title{
The effect of walking upon the utilization of food by sheep
}

\author{
BY J. L. CLAPPERTON \\ Hannah Dairy Research Institute, Ayr \\ (Received 24 April r963-Accepted 7 October 1963)
}

The amount of exercise taken by sheep varies considerably. It is least under closefolding conditions and greatest when the animals are grazing unfenced areas. Observations show that sheep kept in small paddocks of $I-2$ acres walk about $I \frac{1}{2}$ miles each day (England, 1954) but that those pastured in paddocks of 800 acres walk about 4 miles each day (Cory, 1927). Under hill conditions in Britain, the distances covered may approach this latter figure.

Brody (1945) has shown that the cost of moving I kg of body-weight $\mathrm{I} \mathrm{m}$ horizontally is $0.38 \mathrm{cal}$ in horses and $0.45 \mathrm{cal}$ in cattle. Lusk (193I) quotes values of 0.5 $\mathrm{cal} /$ horizontal kilogram-metre (hor. $\mathrm{kg} \mathrm{m}$ ) in men and $0.59 \mathrm{cal} / \mathrm{hor} . \mathrm{kg} \mathrm{m}$ in dogs. This range in the energy cost of horizontal locomotion between these species suggests that the sheep probably expends about $0.5 \mathrm{cal} / \mathrm{hor}$. $\mathrm{kg} \mathrm{m}$ when it walks, and recent experiments confirm this view (Clapperton, I964). If this is so, a $50 \mathrm{~kg}$ sheep walking $3 \mathrm{~km}$ in $24 \mathrm{~h}$ would increase its energy expenditure by $75 \mathrm{kcal} / 24 \mathrm{~h}$ which represents an increase of less than $10 \%$ of its fasting energy metabolism.

In calculating the output from pasture in terms of animal production, it is usual to make an allowance for the energy cost of walking (Woodman, 1952). For cattle it has been assessed at $\mathrm{I}-3 \mathrm{lb}$ starch equivalent (i.e. 107 $1-3213 \mathrm{kcal}$ net energy for fattening). No such values have been computed for sheep. Woodman's assessment of energy requirements for muscular work in terms of starch equivalents presupposes that the efficiency of utilization of food energy in meeting the energy expenditure of walking is the same as that in fattening. This assumption has not been tested by experiment. The experiments described here were undertaken to find how the efficiency of food utilization changes during exercise.

\section{EXPERIMENTAL}

Animals. A Scottish Blackface wether (sheep D) and a Cheviot wether (sheep H) were used as experimental animals. Both were 2 years old and, before the experiment began, were trained for 2 weeks to walk on a treadmill. They were confined in metabolism cages when not in the respiration apparatus.

Ditt. The food used was artificially dried grass finely ground and made into pellets: it contained $16.2 \%$ crude protein on a dry-matter basis.

Plan of experiment. Seven experiments were made with each sheep in the sequence shown in Table I. In two of these the sheep was starved for 6 days and in the remaining five the amounts of food given were those shown in Table I. Food was given in two equal meals each day at $\mathrm{I} 2 \mathrm{~h}$ intervals. In the experiments with maintenance 
rations a small net loss of energy from the body occurred and with the supermaintenance rations energy was retained. The maintenance and supermaintenance levels of feeding were repeated and are referred to as maintenance $I$ and 2 and supermaintenance $I$ and 2 respectively.

Table 1. Dry-matter intake, as dried grass, of the sheep and the order in which they received the five levels of feeding

$\begin{array}{lcccc}\text { Level of feeding } & \begin{array}{c}\text { Dry-matter } \\ \text { intake } \\ \text { (g/day) }\end{array} & \text { Expt no. } & \begin{array}{c}\text { Dry-matter } \\ \text { intake } \\ (\mathrm{g} / \text { day })\end{array} & \text { Expt no. } \\ \text { Starvation I } & 0 & 2 & 0 & 4 \\ \text { Starvation 2 } & 0 & 12 & 0 & 14 \\ \text { Submaintenance } & 323 & 5 & 316 & 8 \\ \text { Maintenance I } & 633 & 1 & 524 & 3 \\ \text { Maintenance 2 } & 644 & \text { II } & 551 & 13 \\ \text { Supermaintenance 1 } & 764 & 7 & 702 & 6 \\ \text { Supermaintenance 2 } & 1058 & 9 & 950 & 10\end{array}$

In each experiment, energy metabolism was measured during $24 \mathrm{~h}$ periods both when the sheep was exercised on a treadmill within the respiration apparatus and when no exercise was given. In the fasting experiments, the sheep were exercised on the $3^{\text {rd }}$ and $5^{\text {th }}$ days and 'rested' on the Ist, 2nd, $4^{\text {th }}$ and 6th days. During the experiments in which food was given, a preliminary period of ro days was allowed to enable the sheep to become adjusted to their ration; they were placed in the respiration chamber for 12 days. On the first 4 and last 4 days no exercise was given. Exercise was given from the 5 th to the 8 th day inclusive and measurements of metabolism were made on each of the 12 days. The periods in which work was done are referred to as 'work' days and the remainder as 'rest' days.

Amount of exercise. The treadmill belt was driven at a speed of $48.5 \mathrm{~m} / \mathrm{min}(\mathrm{r} \cdot 82$ miles/h) and the sheep walked uphill on a gradient of $I$ in 17 . The length of the period of exercise was varied in inverse proportion to the weight of the sheep at the beginning of the day, in an attempt to keep constant from day to day and from experiment to experiment the total work done by each sheep. The exercise to be given during each day was subdivided into periods not exceeding $3 \circ \mathrm{min}$ to avoid overtiring the animal. The total time spent in walking on the treadmill never exceeded $260 \mathrm{~min}$, which was equivalent to a forward movement of $12.6 \mathrm{~km}$ and an ascent of $742 \mathrm{~m} \mathrm{(7.8} \mathrm{miles} \mathrm{and}$ $2440 \mathrm{ft}$ ).

Methods. Faeces and urine were collected daily, and the faeces from 4 days pooled for analysis. Methane production and the $24 \mathrm{~h}$ respiratory exchange were determined daily. The respiration apparatus was that described by Blaxter, Graham \& Rook (I954) modified by N. McC. Graham and F. W. Wainman of this Institute to include a treadmill. The treadmill consisted of an endless rubber belt supported on rollers and was driven by a constant speed motor through a gear box. A variety of speeds and belt inclinations could be obtained with this apparatus.

Analytical methods. Nitrogen was determined by the Kjeldahl technique, carbon by direct combustion in a stream of oxygen, and calorific value by combustion in an 
oxygen-filled bomb. In the computation of results, the factors of Blaxter \& Rook (1953) were used to convert body retentions of $\mathrm{C}$ and $\mathrm{N}$ into calories retained, and Brouwer's (1957) factors were used to calculate the heat production from the respiratory exchange and urinary $\mathrm{N}$ excretion.

\section{RESULTS}

Behaviour of the sheep. After the training period both sheep were able to perform their allotted work loads without difficulty. Care was taken to ensure that the sheep were standing before the treadmill was started. Observation of the animals showed that they tended to walk in a variable way, alternating short bursts of fast walking with periods of slightly slower movement during which they were carried backwards upon the treadmill belt. They did not lie immediately the treadmill stopped but usually waited for $1-2$ min before doing so. The respiration rate of the animals at the end of a walking period was usually more than 100 respirations/min compared with resting values of $20-40 \mathrm{~min}$. These observations indicate that the work load imposed on the animals was considerable.

Table 2. Mean apparent digestibility ( $\%$ ) of dietary constituents by two sheep during consecutive 4-day periods in which the sheep walked or did not walk during each day

\begin{tabular}{|c|c|c|c|c|c|c|c|}
\hline \multirow[b]{2}{*}{ Sheep } & \multirow[b]{2}{*}{ Level of feeding } & \multicolumn{2}{|c|}{ Dry matter } & \multicolumn{2}{|c|}{ Nitrogen } & \multicolumn{2}{|c|}{ Energy } \\
\hline & & $\begin{array}{c}\text { No } \\
\text { walking }\end{array}$ & $\begin{array}{l}\text { Walking } \\
\text { during } \\
\text { day }\end{array}$ & $\begin{array}{c}\text { No } \\
\text { walking }\end{array}$ & $\begin{array}{c}\text { Walking } \\
\text { during } \\
\text { day }\end{array}$ & $\begin{array}{c}\text { No } \\
\text { walking }\end{array}$ & $\begin{array}{c}\text { Walking } \\
\text { during } \\
\text { day }\end{array}$ \\
\hline $\mathbf{H}$ & $\begin{array}{l}\text { Submaintenance } \\
\text { Maintenance 1 } \\
\text { Maintenance } 2 \\
\text { Supermaintenance I } \\
\text { Supermaintenance } 2\end{array}$ & $\begin{array}{l}68 \cdot 0 \\
65 \cdot 2 \\
67 \cdot 1 \\
65 \cdot 4 \\
63 \cdot 9\end{array}$ & $\begin{array}{l}65 \cdot 7 \\
65 \cdot 8 \\
68 \cdot 1 \\
68 \cdot 5 \\
65 \cdot 5\end{array}$ & $\begin{array}{l}69 \cdot 4 \\
66 \cdot 3 \\
70 \cdot 6 \\
70 \cdot 5 \\
68 \cdot 1\end{array}$ & $\begin{array}{l}67 \cdot 4 \\
65 \cdot 9 \\
70 \cdot 3 \\
71 \cdot 8 \\
69 \cdot 1\end{array}$ & $\begin{array}{l}66 \cdot 3 \\
63 \cdot 8 \\
65 \cdot 9 \\
63 \cdot 9 \\
61 \cdot 9\end{array}$ & $\begin{array}{l}63 \cdot 7 \\
65 \cdot 6 \\
67 \cdot 9 \\
68 \cdot 1 \\
63 \cdot 8\end{array}$ \\
\hline D & $\begin{array}{l}\text { Submaintenance } \\
\text { Maintenance I } \\
\text { Maintenance } 2 \\
\text { Supermaintenance } 1 \\
\text { Supermaintenance } 2\end{array}$ & $\begin{array}{l}64 \cdot 8 \\
65 \cdot 7 \\
64 \cdot 9 \\
64 \cdot 1 \\
63 \cdot 4\end{array}$ & $\begin{array}{l}67 \cdot 0 \\
65 \cdot 7 \\
64 \cdot 1 \\
63 \cdot 4 \\
65 \cdot 5\end{array}$ & $\begin{array}{l}70 \cdot 2 \\
70 \cdot 7 \\
71 \cdot 5 \\
69 \cdot 4 \\
68 \cdot 4\end{array}$ & $\begin{array}{l}71 \cdot 9 \\
70 \cdot 6 \\
69 \cdot 3 \\
66 \cdot 6 \\
70 \cdot 8\end{array}$ & $\begin{array}{l}64 \cdot 4 \\
66 \cdot 1 \\
65 \cdot 6 \\
62 \cdot 9 \\
6 I \cdot I\end{array}$ & $\begin{array}{l}67 \cdot 7 \\
65 \cdot 6 \\
62 \cdot 2 \\
62 \cdot 0 \\
62 \cdot 8\end{array}$ \\
\hline
\end{tabular}

The 'no walking' results are the means of two periods of 4 days each. The 'walking during day' results are the mean of one 4 -day period during which the sheep walked for some $4 \mathrm{~h}$ daily.

Apparent digestibility of the dry matter, crude protein and energy of the food. The apparent digestibility of energy was about $3 \circ 0$ units of digestibility lower at the supermaintenance levels of feeding than at the submaintenance level. This effect was not significant statistically. There were no significant differences between the two determinations of apparent digestibility made when the sheep were resting in the periods before and after that in which they walked. The apparent digestibility of the dietary dry matter increased slightly when the animals walked, but there was no effect upon the apparent digestibility of the crude protein and energy.

Methane production. Table 3 shows the methane production of the sheep during rest and during exercise. The resting values are the means for the initial and final periods of 
rest, there being no significant difference between these periods. The results show, in agreement with those obtained by Blaxter \& Graham (I955), that when food intake was increased methane production per unit food declined. In eight of ten experiments, methane production was slightly greater during exercise than during rest.

Table 3. Mean production of methane by two sheep at different feeding levels on days on which the sheep walked or did not walk

$\begin{array}{clcc}\text { Sheep } & \text { Level of feeding } & \begin{array}{c}\text { No } \\ \text { walking }\end{array} & \begin{array}{c}\text { Walking } \\ \text { during } \\ \text { day }\end{array} \\ \text { H } & \text { Submaintenance } & 7 \cdot 12 & 7.68 \\ & \text { Maintenance I } & 6.51 & 6.70 \\ & \text { Maintenance 2 } & 4 \cdot 92 & 5.41 \\ & \text { Supermaintenance I } & 6.09 & 6.26 \\ & \text { Supermaintenance 2 } & 5.19 & 5.03 \\ \text { D } & \text { Submaintenance } & 6.93 & 6.76 \\ & \text { Maintenance I } & 6.17 & 6.40 \\ & \text { Maintenance 2 } & 5.56 & 5.64 \\ & \text { Supermaintenance I } & 5.19 & 5.60 \\ & \text { Supermaintenance 2 } & 5.26 & 5.45 \\ & \text { Mean with sE } & 5.89 \pm 0.098 & 6.09 \pm 0.140\end{array}$

$N$ metabolism. The mean daily excretion of $\mathrm{N}$ in the urine is shown in Table 4 . The results, though variable, may be divided into the three groups shown at the foot of Table 4 according to the amount of food given. The values obtained in fasting and in experiments at the maintenance and submaintenance levels showed very little difference between the amount of $\mathrm{N}$ excreted on rest days and that excreted on working days. In the supermaintenance experiments, however, there was an increase of $1.56 \mathrm{~g}$ in the amount of $\mathrm{N}$ excreted on work days over that excreted on rest days. If it is assumed that this additional $\mathrm{N}$ represents protein synthesized during the rest period but not during the work period, exercise resulted in the oxidation of $55 \mathrm{kcal}$ protein in the supermaintenance experiments.

Energy metabolism. Energy retention computed from retentions of $\mathrm{C}$ and $\mathrm{N}$ agreed with those computed from the heat of combustion of the food and excreta and the heat production determined from respiratory exchange measurements. The results obtained by the two methods were therefore averaged and the mean values in relation to the intake of metabolizable energy by the sheep are plotted in Fig. I.

By iteration, regression lines were fitted to the values above and below the maintenance level so that the lines relating energy retention to metabolizable energy intake at rest and at work were parallel to each other and that the lines above and below the maintenance level at rest and at work intersected the line of zero energy balance at the same points. Below maintenance, when energy retention was negative, the pooled regression coefficient of energy retention on metabolizable energy was $0.755 \mathrm{kcal}$ retained $/ \mathrm{kcal}$ metabolizable energy. The efficiency with which the metabolizable energy of normal foods is used to maintain sheep that are not exercised varies about 
a mean of $74 \%$ (Blaxter, 196r). The two regression coefficients obtained in these experiments thus agree with the above estimate whether the sheep were exercised or not. The difference between the intercepts of the regressions is an estimate of the apparent cost of the work load when the sheep were not gaining energy and it was, for both sheep, $469 \mathrm{kcal}$.

Table 4. Mean daily excretion of nitrogen in the urine of sheep at different feeding levels on days on which the sheep walked or did not walk

\begin{tabular}{|c|c|c|c|}
\hline \multirow[b]{2}{*}{ Sheep } & \multirow[b]{2}{*}{ Level of feeding } & \multicolumn{2}{|c|}{$\begin{array}{l}\text { Excretion of urinary } N \\
(\mathrm{~g} / 24 \mathrm{~h})\end{array}$} \\
\hline & & $\begin{array}{c}\text { No } \\
\text { walking }\end{array}$ & $\begin{array}{l}\text { Walking } \\
\text { during } \\
\text { day }\end{array}$ \\
\hline $\mathrm{H}$ & $\begin{array}{l}\text { Starvation I } \\
\text { Starvation } 2 \\
\text { Submaintenance } \\
\text { Maintenance I } \\
\text { Maintenance } 2 \\
\text { Supermaintenance I } \\
\text { Supermaintenance } 2\end{array}$ & $\begin{array}{r}6 \cdot 68 \\
7 \cdot 62 \\
4 \cdot 30 \\
9 \cdot 79 \\
10 \cdot 39 \\
6 \cdot 35 \\
11 \cdot 76\end{array}$ & $\begin{array}{r}2.99^{*} \\
7.43 \\
3.71 \\
9.57 \\
10.38 \\
8.74 \\
13.35\end{array}$ \\
\hline $\mathrm{D}$ & $\begin{array}{l}\text { Starvation I } \\
\text { Starvation } 2 \\
\text { Submaintenance } \\
\text { Maintenance I } \\
\text { Maintenance } 2 \\
\text { Supermaintenance I } \\
\text { Supermaintenance } 2\end{array}$ & $\begin{array}{r}6 \cdot 21 \\
7 \cdot 40 \\
6 \cdot 76 \\
10 \cdot 68 \\
9 \cdot 18 \\
7 \cdot 32 \\
10 \cdot 66\end{array}$ & $\begin{array}{r}7.06 \\
7 \cdot 24 \\
6 \cdot 54 \\
9 \cdot 15 \\
10 \cdot 17 \\
6.84 \\
\times 3.37\end{array}$ \\
\hline Mean values & $\begin{array}{l}\text { Starvation } \\
\text { Submaintenance and } \\
\text { maintenance } 1 \text { and } 2 \\
\text { Supermaintenance } 1 \text { and } 2\end{array}$ & $\begin{array}{l}6 \cdot 98 \\
8 \cdot 52 \\
9 \cdot 02\end{array}$ & $\begin{array}{r}6 \cdot 18 \\
8 \cdot 25 \\
10 \cdot 58\end{array}$ \\
\hline
\end{tabular}

- Sheep H produced no urine on 1 day during this experiment.

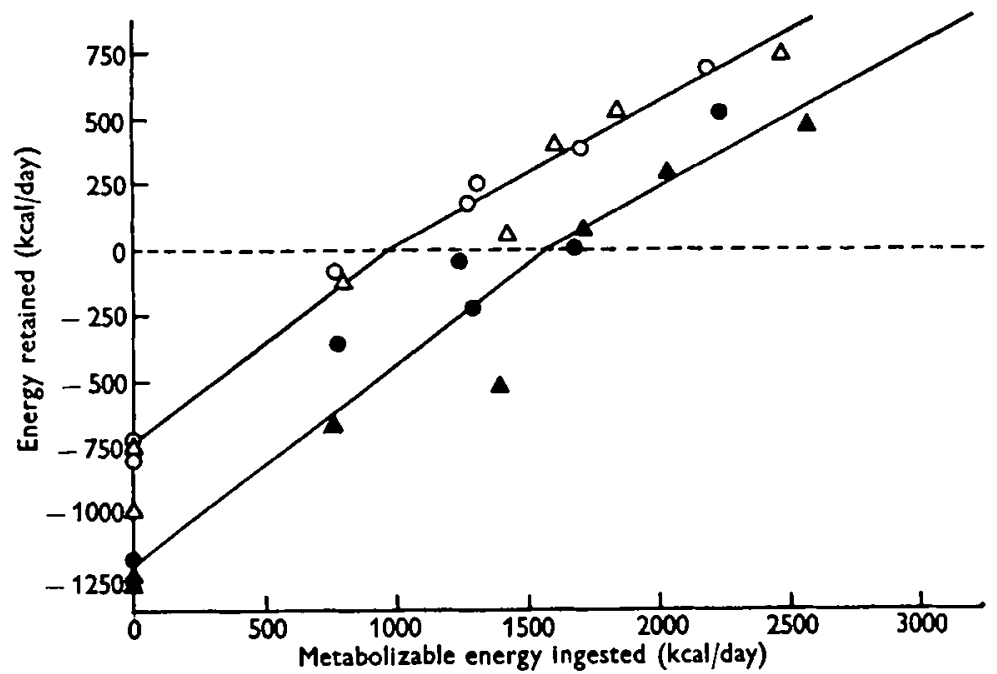

Fig. I. Effect of walking upon the amount of energy retained by sheep. $\Delta$, sheep $H$, resting; $\Delta$, sheep $H$, walking; 0 , sheep $D$, resting; $\bullet$, sheep $D$, walking. 
Above the maintenance level, when the animals were storing energy, the pooled regression coefficient of energy retention on metabolizable energy intake was 0.537 . This value is in agreement with expectation. The efficiency of fat storage expressed as kcal energy retained/100 kcal metabolizable energy given above maintenance varies with the nature of the food, and Armstrong (r960) found an efficiency of $57 \%$ for dried grass of similar composition. The mean apparent cost of work determined as the difference between intercepts of the regression equations was $330 \mathrm{kcal}$. The apparent cost of walking measured in terms of its effect on energy retention was thus smaller in sheep in positive energy balance at supermaintenance levels of feeding than in sheep given insufficient food to maintain the energy balance. The difference between the apparent costs of the same work load borne by animals losing energy owing to insufficient food and those gaining energy was statistically significant.

\section{DISCUSSION}

Exercise increased the apparent digestibility of the dry matter of the food and resulted in a small increase in methane production amounting to $0.20 \mathrm{kcal} / \mathrm{r} 00 \mathrm{kcal}$ food ingested. Since exercise increases body temperature it is possible that rates of fermentation in the rumen may have been enhanced by exercise, thus accounting for these small effects.

Observation of the animals always gave the impression that the speed of the treadmill was such that they were walking at a speed close to the maximum one they could attain. Apart from one fall by each animal during the training period, however, neither sheep had any difficulty in performing the work required of it. It thus appears that the instantaneous work load imposed on the animals was the maximum conveniently attainable and an increase in the total work done in a $24 \mathrm{~h}$ period could be obtained only by increasing the duration of the walking period. When the energy retention of the sheep was negative, the imposed work load did not appear to affect the efficiency with which metabolizable energy was used to maintain the energy balance and it did not reduce the $\mathrm{N}$ retention. With a negative energy retention the energy required for walking was thus derived entirely from body fat and may therefore be regarded as an additional charge on the maintenance requirement of the animal.

Above the maintenance level of feeding when energy was retained, more protein was metabolized when the sheep were walking than when they were at rest. The apparent cost of work measured by the reduction in energy retention which it induced was $330 \mathrm{kcal}$, of which $55 \mathrm{kcal}$ were derived from the oxidation of protein. Protein energy was thus $17 \%$ of the total energy lost. Previous results have shown (Armstrong \& Blaxter, I957; Blaxter \& Martin, 1962) that 10-20\% of the energy stored by sheep of this age is stored as protein, and the finding that similar proportions were lost during exercise by animals that were fattening indicates that the imposition of a work load caused a diversion of the metabolizable energy surplus to maintenance needs from the production of new tissue to muscular work. The $\mathrm{N}$ which would have been stored as protein together with fat in this tissue was thus eliminated in the urine. The difference in the mean energy cost of muscular work measured by the change it 
induced in energy retention was less in sheep gaining energy than in those losing it. This finding suggests that muscular work must be regarded as a maintenance charge upon the animal. This charge must be met before any surplus metabolizable energy is available for the production of fat. The effect of exercise is to increase the energy required for maintenance and, as shown in Fig. I, it results in a displacement to the right of the lines relating metabolizable energy intake to energy retention. Consequently, the apparent cost of a given amount of work, judged by differences in energy retention observed when constant rations are given to a resting sheep and to the same sheep when exercised, appears to be smaller when the animal is retaining energy than when it is losing energy. The additional metabolizable energy required to enable the animal to maintain constant its energy retention for a given work load is, however, not affected by the level of feeding.

\section{SUMMARY}

I. In fourteen calorimetric experiments each lasting 12 days, the energy metabolism of two sheep was measured both when the animals were exercised by walking on a treadmill (on the $5^{\text {th- }}$-8th days inclusive) and when they were resting on the first 4 and last 4 days. In ten of these experiments food was given and in four the sheep were starved. On a typical day the animals walked $12 \cdot 6 \mathrm{~km}$ and ascended $742 \mathrm{~m}$.

2. When the animals walked for about $4 \mathrm{~h}$ daily the apparent digestibility of the dry matter of the ration was slightly increased but there was no effect upon the apparent digestibility of the crude protein and energy. Walking tended to increase the amount of methane produced by the sheep.

3. When the sheep at rest were losing energy from their bodies, exercise had no effect upon the excretion of nitrogen in the urine. When the sheep at rest were retaining energy, however, the $\mathrm{N}$ excretion in the urine increased when exercise was imposed. The reduced synthesis of protein accounted for $17 \%$ of the energy required to perform the work load.

4. Walking did not affect the efficiency with which metabolizable energy was used either to meet the maintenance needs of the sheep or for the production of fat. The apparent cost of the work load below maintenance was $469 \mathrm{kcal}$ and above maintenance $330 \mathrm{kcal}$. This difference was statistically significant and is accounted for by the diversion of metabolizable energy from fat deposition to oxidation when the animals which were retaining energy at rest were exercised.

My thanks are due to Dr K. L. Blaxter for advice during the course of the experiments and for undertaking the starvation experiments.

\section{REFERENCES}

Armstrong, D. G. (1960). Proc. int. Grassl. Congr. vin. Reading, p. 487.

Armstrong, D. G. \& Blaxter, K. L. (1957). Brit. F. Nutr. II, 4 I3.

Blaxter, K. I. (1961). EAAP Publ. no. 1o, p. 21 r.

Blaxter, K. L. \& Graham, N. McC. (1955). F. agric. Sci. 46, 292.

Blaxter, K. L.., Graham, N. McC. \& Rook, J. A. F. (1954). F. agric. Sci. 45, 10.

Blaxter, K. L. \& Martin, A. K. (1962). Brit. F. Nutr. 16, 397.

Blaxter, K. L. \& Rook, J. A. F. (1953). Brit. F. Nutr. 7, 83 . 
Brody, S. (1945). Bioenergetics and Growth, p. 907. New York: Reinhold Publishing Corp. Brouwer, E. (1957). Acta physiol. pharmacol. néerl. 6, 795.

Clapperton, J. L. (1964). Brit. F. Nutr. 18, 47.

Cory, V. L. (1927). Bull. Tex. agric. Exp. Sta. no. 367.

England, G. J. (1954). Brit. Y. Anim. Behav. 2, 56.

Lusk, G. (1931). Elements of the Science of Nutrition, 4 th ed., reprinted, p. 431 . London: Saunders.

Woodman, H. E. (1952). Bull. Minist. Agric., Lond., no. 48, izth ed. 